\title{
Development and Optimization of Naproxen Sodium Controlled Release Tablets: QbD Approach
}

\author{
Atul Phatak $^{1, *}$, Dhanashri Joshi ${ }^{1}$, Mahesh Bhadgale ${ }^{2}$, Pravin Chaudhari ${ }^{1}$ \\ 1'Department of Pharmaceutics, PES's Modern College of Pharmacy, Sector 21, Yamunanagar, Nigdi, Pune, Maharashtra, INDIA. \\ ${ }^{2}$ Department of Formulation Research and Development, Callidus Research Labs, Chakan Industrial Area, Nighoje, Pune, \\ Maharashtra, INDIA.
}

\begin{abstract}
Objectives: The aim of present study was to formulate and optimize Multi-unit Naproxen Sodium controlled release tablet by $\mathrm{QbD}$ approach. Controlled release dosage form for naproxen sodium was selected to reduce dosing frequency and gastrointestinal side effects of drug. Methods: Naproxen Sodium CR tablets were prepared by using wet granulation method by employing Quality by Design ( $Q b D)$. This tablet was made by a mixture of a granulate having an immediate release with a granulate having a controlled release, in terms of the active ingredient. Eudragit RSPO and RLPO polymers were used to control the drug release. Optimization of tablet formulation was done using $2^{3}$ factorial design to study the effect of concentration of Eudragit RSPO, Eudragit RLPO polymers and concentration of disintegrating agent i.e. crospovidone on disintegration time and $\mathrm{f} 2$ factor of drug released. Tablets were evaluated for thickness, hardness, friability, assay and drug release. Results: Optimized formulation shows controlled drug release profile upto $14 \mathrm{hrs}$. with disintegration time of $88 \mathrm{~min}$. Conclusion: It was concluded that tablet formulation of Naproxen Sodium CR tablets employing QbD leads to a single dose per day in the management of rheumatoid arthritis and also concluded that Eudragit RLPO and Eudragit RSPO polymers can be successfully used to controlled drug release profile of tablet.
\end{abstract}

Key words: Multi-unit-controlled release system, Quality by Design, Design of experiment, Eudragit RLPO, Eudragit RSPO.

\section{INTRODUCTION}

Quality by Design (QbD) is a systemic approach to pharmaceutical development that begins with predefined objectives and emphasizes product and process understanding and process control, based on sound science and quality risk management. ${ }^{1}$ One of the major parameters in $\mathrm{QbD}$ is developing a design space which includes equipment, excipients and manufacturing environment. To ensure better quality of product, the product variables are periodically monitored in design space. Large scale productivity can be improved by applying QbD approach. Hence, this approach is beneficial from market point of view. ${ }^{2}$

Multiple-units composition is used for administration of a therapeutically effective amount of NSAID to obtain both a relatively fast or quick onset of therapeutic effect and maintenance of therapeutically active plasma concentration for a relatively long period of time. ${ }^{3}$

Naproxen Sodium Is Non-steroidal Antiinflammatory (NSAID) drug which is widely used in the treatment of arthritis and as analgesic and antipyretic in the treatment of mild to moderate pain, such as dysmenorrhea or arthritis. This drug is acting by blocking COX-1 and COX-2 enzymes thereby inhibit prostaglandin synthesis and gives analgesic and antiinflammatory effect. Inhibition of COX-1 is related with gastrointestinal and renal toxicity, while inhibition of COX-2 gives
Submission Date: 13-08-2019; Revision Date: 27-09-2019; Accepted Date: 26-02-2020

DOI: 10.5530/ijper.54.2s.67 Correspondence: Dr. Atul Phatak,

Department of Pharmaceutics, P.E.S's Modern College of Pharmacy, Nigdi, Pune-411044, Maharashtra, INDIA.

Phone: +919822449380

E-mail: atulapin@yahoo.com

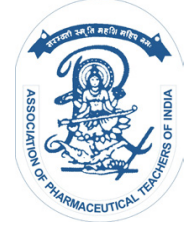

www.ijper.org 
anti-inflammatory activity. ${ }^{4,5}$ In these new formulations, drug from IR granules was released in a short time, so that it quickly develop its therapeutic action and reach therapeutic blood levels, while the remaining portion of the drug in CR granules was released in a longer interval of time so as to maintain therapeutic concentration until subsequent administration. These therapeutic concentrations can even last twenty-four hours. ${ }^{6}$ The objective of research work was to develop controlled released multi-particulate Naproxen Sodium tablet employing $\mathrm{QbD}$ approach to reduce the dosing frequency and adverse GI side effect of drug.

\section{MATERIALS AND METHODS Materials}

Naproxen Sodium was obtained from Divis Laboratories Limited, India. Eudragit RLPO, Eudragit RSPO and Eudragit L100 were supplied by S. Zhaveripharmakem Pvt. Ltd, Dombiveli, Maharashtra. Citric acid was from Merck India Ltd, Mumbai. Crospovidone was from Signet Industries Ltd, Mumbai. Magnesium stearate was obtained from Peter Greven GmbH and Co. KG, Germany. Microcrystalline cellulose was obtained from JRS Pharma GmbH and Co. KG, Germany. Povidone K-30 and all other ingredients used throughout the study were of analytical grade.

\section{Methods}

\section{Quality Target Product Profile for Naproxen sodium CR Tablets}

QTTP is the prospective summary of the quality characteristics of a drug product that ideally ensure the desired quality, taking into account safety and efficacy of the drug product. ${ }^{7}$ Brief explanation about QTTP that affects formulation of Naproxen Sodium CR Tablets shown in Table 1.

\section{Identification of critical and non-critical quality attributes (CQAs) for Naproxen Sodium CR Tablets}

CQAs were established based on the QTTP's defined in the above table for the development of Naproxen sodium CR tablets. The attributes which are related to the safety of the formulated product and which have a potential effect on formulation variable during development of process are termed as CQA., ${ }^{2,8}$ Brief explanation about CQA's were depicted in Table 2.

\section{Manufacturing process of Naproxen sodium CR Tablets using DOE \\ Experimental Design}

A $2^{3}$ factorial design with 3 center points were employed to optimize the tablet formula.
In this design independent factors were concentration of Eudragit RSPO, Eudragit RLPO polymers and concentration of disintegrating agent i.e. Crospovidone. Disintegration time and F2 factor of drug released were selected as responses. The coded values of design for Naproxen Sodium CR tablets are given in Table 3.

\section{Preparation of Naproxen Sodium CR Tablets}

Tablets were formulated by using following procedure., ${ }^{910}$

i. Preparation of $\mathbf{C R}$ granules: Weighed quantity of naproxen sodium, citric acid, Eudragit RLPO, Eudragit RSPO were passed through 30 \# sieve and dry mixed for 5 min. Wet granulation was done by using Eudragit L binder solution. Semi-dried granules were passed through 20\# Sieve. Granules were dried at $40^{\circ} \mathrm{C}$ for $20 \mathrm{~min}$.

ii. Preparation of IR granules: Weighed quantity of naproxen sodium and MCC $\mathrm{pH} 101$ were passed through 30 \# sieve and dry mixed for $5 \mathrm{~min}$. Wet granulation was done by using povidone $\mathrm{K}-30$ binder solutions, granules were dried at $60^{\circ} \mathrm{C}$ for half hour and passed through 30\# sieve.

iii. Blending of $C R$ and IR granules with extra granular part: CR and IR granules were blended with MCC pH 102, crospovidone for $15 \mathrm{~min}$ at $14 \mathrm{rpm}$. and lubrication was done with magnesium stearate for $10 \mathrm{~min}$. Then blend was compressed into tablets. Composition for all batches of Naproxen sodium CR tablet is shown in Table 4.

\section{Characterization of CR and IR granules ${ }^{11,12}$}

\section{Bulk density}

Bulk density was measured by pouring $20 \mathrm{~g}$ of the granules (W) into a $100 \mathrm{ml}$ measuring cylinder and the initial volume was noted. This volume was considered as bulk volume. From this, the bulk density was calculated by using formula given below.

$$
\text { Bulk density }=\mathrm{W} / \mathrm{V}_{\mathrm{b}}
$$

Where $\mathrm{W}=$ Weight of the granules and $\mathrm{V}_{\mathrm{b}}=$ Bulk volume of the granules.

\section{Tapped density}

Tapped density is defined as the ratio of total mass of granules to the tapped volume of powder. Tapped volume was measured by tapping the granules for 100 times. Tapped density was calculated by using formula given below.

$$
\text { Tapped density }=\mathrm{W} / \mathrm{V}_{\mathrm{t}}
$$

Where $\mathrm{W}=$ Weight of the granules and $\mathrm{V}_{\mathrm{t}}=$ Tapped volume of granules. 
Table 1: QTTP of Naproxen Sodium CR Tablets.

\begin{tabular}{|c|c|c|}
\hline QTPP Element & Target & Justification \\
\hline Dosage form & Tablet & $\begin{array}{c}\text { ANDA needs same dosage form as that of Reference } \\
\text { product }\end{array}$ \\
\hline Dosage Design & Controlled Release tablets & Controlled Release design needed to meet label claim. \\
\hline Route of administration & Oral & $\begin{array}{l}\text { Pharmaceutical equivalence requirement: Same route of } \\
\text { administration }\end{array}$ \\
\hline Dosage strength & Naproxen Sodium CR Tablets 750 mg & $\begin{array}{l}\text { Pharmaceutical equivalence requirement: Same strength } \\
\text { as that of Reference product. }\end{array}$ \\
\hline Pharmacokinetics & $\begin{array}{l}\text { Fasted and Fed condition Bioequivalence } \\
\text { study. }\end{array}$ & $\begin{array}{l}\text { Bioequivalence requirement } \\
\text { Initial plasma concentration through the first two hours } \\
\text { that provides a clinically significant therapeutic effect } \\
\text { followed by a sustained plasma concentration that } \\
\text { maintains the therapeutic effect }\end{array}$ \\
\hline Stability & $\begin{array}{l}\text { At least 24-month shelf-life at room } \\
\text { temperature }\end{array}$ & Equivalent to or better than RLD shelf-life \\
\hline $\begin{array}{l}\text { Drug product quality } \\
\text { attributes }\end{array}$ & $\begin{array}{c}\text { Physical Attributes Identification Assay } \\
\text { Weight variation Residual Solvents Drug } \\
\text { Release Related Substances Water } \\
\text { Content }\end{array}$ & $\begin{array}{l}\text { Pharmaceutical equivalence requirement : Meeting the } \\
\text { same compendia or other applicable (quality) standards } \\
\text { (i.e., identity, assay, purity and quality) }\end{array}$ \\
\hline Container Closure System & $\begin{array}{l}\text { Suitable container closure system to } \\
\text { achieve the target shelf-life and to ensure } \\
\text { tablet integrity during shipping. }\end{array}$ & $\begin{array}{c}\text { HDPE bottles with Child Resistant (CR) Caps are selected } \\
\text { based on similarity to the RLD packaging. No further } \\
\text { special protection is needed due to the stability of drug } \\
\text { substance }\end{array}$ \\
\hline
\end{tabular}

\begin{tabular}{|c|c|c|c|c|}
\hline \multicolumn{2}{|c|}{ Drug Product quality attributes } & \multirow{3}{*}{$\begin{array}{c}\text { Target } \\
\text { Color and shape acceptable } \\
\text { to the patient. No visual tablet } \\
\text { defects observed. }\end{array}$} & \multirow{3}{*}{$\begin{array}{l}\text { Is this } \\
\text { critical? } \\
\text { No }\end{array}$} & \multirow{3}{*}{$\begin{array}{l}\text { Justification of Criticality } \\
\text { Commercial requirement. }\end{array}$} \\
\hline \multirow[b]{3}{*}{ Physical Attributes } & $\begin{array}{l}\text { Description } \\
\text { and Color }\end{array}$ & & & \\
\hline & Shape & & & \\
\hline & Size & Similar to RLD & Yes & $\begin{array}{l}\text { Tablet size correlates to swallowability; therefore, } \\
\text { it is critical. For comparable ease of swallowing as } \\
\text { well as patient acceptance and compliance with } \\
\text { treatment regimens, the target for tablet size and } \\
\text { volume is set similar to the RLD. }\end{array}$ \\
\hline \multicolumn{2}{|c|}{ Water Content } & Not more than $2.0 \% \mathrm{w} / \mathrm{w}$ & No & $\begin{array}{l}\text { Limited amounts of water in oral solid dosage } \\
\text { forms will not impact patient safety or efficacy. } \\
\text { Therefore, it is not critical. }\end{array}$ \\
\hline \multicolumn{2}{|c|}{ Weight Variation } & $\begin{array}{l}\text { Complies with Pharmacopoeial } \\
\text { requirement }\end{array}$ & Yes & $\begin{array}{c}\text { Manufacturing process impact weight variation of } \\
\text { drug product. }\end{array}$ \\
\hline \multicolumn{2}{|c|}{ Dose Uniformity } & $\begin{array}{l}\text { Complies with Pharmacopoeial } \\
\text { requirement for uniformity of } \\
\text { dosage units }\end{array}$ & Yes & $\begin{array}{l}\text { Both formulation and process impact the } \\
\text { uniformity. }\end{array}$ \\
\hline \multicolumn{2}{|c|}{ Assay of Naproxen Sodium } & $90 \%-110 \%$ of label claim & Yes & $\begin{array}{l}\text { Variability in assay will affect safety and efficacy; } \\
\text { therefore, assay is critical. }\end{array}$ \\
\hline \multicolumn{2}{|c|}{$\begin{array}{c}\text { Dissolution Media: } \mathrm{pH} 7.4 \text { Phosphate } \\
\text { buffer, Type: USP-II(Paddle), Media } \\
\text { Volume: } 900 \mathrm{ml}, \text { Speed: } 50 \text { RPM } \\
\text { Time points: } 0.5,1,2,3,4,6,8,10,12 \\
14 \mathrm{hr} .\end{array}$} & $\begin{array}{l}\text { Similar drug release profile } \\
\text { as RLD using a predictive } \\
\text { dissolution method (as per } \\
\text { USP) }\end{array}$ & Yes & $\begin{array}{l}\text { The drug release profile is important for BA and } \\
\text { BE; therefore, it is critical. For tablets containing a } \\
\text { multi-particulate system, a non-uniform distribution } \\
\text { of CR granules may cause different drug release } \\
\text { in tablet. Therefore, it is critical. }\end{array}$ \\
\hline \multicolumn{2}{|c|}{ Related Substances/Impurities } & $\begin{array}{l}\text { Individual unknown } \\
\text { degradation product: NMT } \\
0.2 \% \text { Total degradation } \\
\text { products: NMT } 1.0 \%\end{array}$ & Yes & $\begin{array}{l}\text { The limit of degradation products is critical to drug } \\
\text { product safety. The limit for individual unknown } \\
\text { degradation products complies with ICH Q3B. A } \\
\text { limit for the total degradation products is set based } \\
\text { on analysis of the RLD near expiry. }\end{array}$ \\
\hline
\end{tabular}




\section{Compressibility index}

It can be calculated by using following formula.

DPPH radical scavenging effect $(\%)=\frac{\text { Abs control }- \text { Abs sample }}{\text { Abs control } \times 100}$

A material having values of less than $20 \%$ has good flow property.

\section{Hauser's Ratio}

Hausner's ratio is an indirect way of accessing the ease of granules flow. It was calculated by the ratio of tapped density to the bulk density.

$\%$ Moisture content $=\frac{\text { Initial weight }- \text { Final weight }}{\text { Initial weight }}$

\section{Table 3: Coded values of design.}

\begin{tabular}{|c|c|c|c|}
\hline Sr. No. & Name & Low (-1) & High (+1) \\
\hline 1 & $\mathrm{X}_{1}$ (Eudragit RL PO) & 54.5 & 94.5 \\
\hline 2 & $\mathrm{X}_{2}$ (Eudragit RS PO) & 129 & 169 \\
\hline 3 & $\mathrm{X}_{3}$ (Crospovidone) & 142.25 & 182.25 \\
\hline
\end{tabular}

\section{Evaluation of Naproxen Sodium CR Tablets ${ }^{11,12}$ Weight Variation}

Weight variation test was done by weighing 20 tablets individually, calculating the average weight and comparing the individual weights to the average. Standard deviation were calculated and checked with the standard USP pharmacopoeial limits.

\section{Thickness and Diameter}

10 tablets were randomly picked from each batch and their thickness and diameter were measured using a calibrated dial Vernier caliper (Mitutoya Digimatic Caliper, Kanagawa Japan). ( $\pm 5 \%$ is allowed).

\section{Hardness}

The hardness of each batch of tablet was checked by using Erweka hardness tester. The hardness was measured in terms of Newton (N). 5 tablets were chosen randomly and tested for hardness.

\section{Friability}

20 tablets were weighed and the initial weight of these tablets was recorded and placed in Roche friabilator (Model 902, EI product, Panchkula, India) and rotated at the speed of $25 \mathrm{rpm}$ for 100 revolutions. Then

\begin{tabular}{|c|c|c|c|c|c|c|c|c|c|c|c|c|}
\hline \multirow{2}{*}{ Sr.no } & \multirow{2}{*}{$\begin{array}{c}\text { Name of } \\
\text { Ingredient }\end{array}$} & \multicolumn{11}{|c|}{ Quantity in mg/tab } \\
\hline & & F1 & F2 & F3 & F4 & F5 & F6 & F7 & F8 & F9 & F10 & F11 \\
\hline \multicolumn{13}{|c|}{ CR granulate part } \\
\hline 1 & $\begin{array}{l}\text { Naproxen } \\
\text { Sodium }\end{array}$ & 577.5 & 577.5 & 577.5 & 577.5 & 577.5 & 577.5 & 577.5 & 577.5 & 577.5 & 577.5 & 577.5 \\
\hline 2 & Citric acid & 82.5 & 82.5 & 82.5 & 42.5 & 42.5 & 82.5 & 82.5 & 82.5 & 122.5 & 82.5 & 122.5 \\
\hline 4 & Eudragit RLPO & 94.5 & 74.5 & 74.5 & 94.5 & 94.5 & 54.5 & 54.5 & 74.5 & 54.5 & 94.5 & 54.5 \\
\hline 5 & Eudragit RSPO & 129 & 149 & 149 & 169 & 169 & 169 & 169 & 149 & 129 & 129 & 129 \\
\hline \multicolumn{13}{|c|}{ Binder } \\
\hline 6 & Eudragit L 100 & 46.5 & 46.5 & 46.5 & 46.5 & 46.5 & 46.5 & 46.5 & 46.5 & 46.5 & 46.5 & 46.5 \\
\hline 7 & Ethanol & q.s. & q.s. & q.s. & q.s. & q.s. & q.s. & q.s. & q.s. & q.s. & q.s & q.s \\
\hline \multicolumn{13}{|c|}{ IR granulate part } \\
\hline 8 & $\begin{array}{l}\text { Naproxen } \\
\text { Sodium }\end{array}$ & 247.5 & 247.5 & 247.5 & 247.5 & 247.5 & 247.5 & 247.5 & 247.5 & 247.5 & 247.5 & 247.5 \\
\hline 9 & MCC 101 & 45.05 & 45.05 & 45.05 & 45.05 & 45.05 & 45.05 & 45.05 & 45.05 & 45.05 & 45.05 & 45.05 \\
\hline \multicolumn{13}{|c|}{ Binder } \\
\hline 10 & Povidone K-30 & 2.95 & 2.95 & 2.95 & 2.95 & 2.95 & 2.95 & 2.95 & 2.95 & 2.95 & 2.95 & 2.95 \\
\hline 11 & Water & q.s & q.s & q.s & q.s & q.s & q.s & q.s & q.s & q.s & q.s & q.s \\
\hline \multicolumn{13}{|c|}{ Extra-granular part } \\
\hline 12 & Crospovidone & 182.2 & 162.2 & 162.2 & 142.2 & 182.2 & 142.2 & 182.2 & 162.2 & 142.2 & 142.2 & 182.2 \\
\hline 13 & MCC 102 & 15.25 & 35.25 & 35.25 & 55.25 & 15.25 & 55.25 & 15.25 & 35.25 & 55.25 & 55.25 & 15.25 \\
\hline 14 & $\begin{array}{l}\text { Magnesium } \\
\text { stearate }\end{array}$ & 10 & 10 & 10 & 10 & 10 & 10 & 10 & 10 & 10 & 10 & 10 \\
\hline
\end{tabular}

Tablet weight- $1433 \mathrm{mg}$ 
tablets were removed from the friabilator dusted off the fines and again weighed and the weight was recorded. Percentage friability was calculated by using the formula:

$$
\text { Tensile strength }=\frac{\mathrm{N}}{\mathrm{mm}^{2}}=\frac{\text { Load at failure } \times 100}{\text { Strip thickness } \times \text { Strip width }}
$$

\section{Disintegration Test}

The disintegration time of tablet was determined by using Disintegration test apparatus. 6 tablets were randomly selected and placed them in the disintegration basket containing $900 \mathrm{ml}$ of water, maintained the temperature at $37 \pm 2^{\circ} \mathrm{C}$. Time taken for complete disintegration of tablets was noted.

\section{In vitro dissolution study}

The in-vitro dissolution studies were performed using the USP-II (Paddle) dissolution apparatus (Lab India, DS 8000, Mumbai, India) at $50 \mathrm{rpm}$. Dissolution media was phosphate buffer $\mathrm{pH} 7.4$ for 14 hrs. and temperature was maintained at $37 \pm 0.5^{\circ} \mathrm{C}$. Sampling time interval set at: $30 \mathrm{~min}, 1,2,3,4,6,8,10,12$ and $14 \mathrm{hr}$. After each time interval $5 \mathrm{ml}$ was withdrawn and same volume of fresh medium was replaced. The withdrawn samples were diluted with $\mathrm{pH}$ 7.4, filtered and analyzed on UV spectrophotometer (Shimatzu UV 1800) at $332 \mathrm{~nm}$ using pH 7.4 as a blank. Percentage drug release was calculated.

\section{Assay of Tablet ${ }^{13}$}

Assay of Naproxen Sodium CR tablet was performed by using following procedure.

\section{- Preparation of standard solution}

Weighed $23 \mathrm{mg}$ of naproxen sodium and transferred into the $50 \mathrm{ml}$ volumetric flask, added sufficient water to dissolve the drug. Sonicate this solution for $15 \mathrm{~min}$. After sonication volume was make up to $50 \mathrm{ml}$ with water. Pipette out $10 \mathrm{ml}$ of this solution and diluted up to $50 \mathrm{ml}$ with water.

\section{- Preparation of sample solution}

20 tablets were weighed and powdered. Weighed quantity of powder equivalent to $600 \mathrm{mg}$ of Naproxen sodium API.Transferred into $100 \mathrm{ml}$ volumetric flak and add $50 \mathrm{ml}$ water and sonicate this solution for $30 \mathrm{~min}$. Finally make up the volume with water.

Pipette out $3 \mathrm{ml}$ of this solution and transferred into $200 \mathrm{ml}$ volumetric flask. Add sufficient water and sonicate it for $15 \mathrm{~min}$.

Both the solution was analyzed by UV spectrophotometer. Assay of tablet was calculated by below formula.

$$
\mathrm{CI}=\frac{\text { Tapped Density }- \text { Bulk Density }}{\text { Tapped Density }} \times 100
$$

\section{Similarity factor ${ }^{14}$}

Similarity factor (f2) is a logarithmic reciprocal square root transformation of the sum of squared error and is a measurement of the similarity in percentage (\%) dissolution between two curves. Similarity factor can be found out by using following formula.

$$
\mathrm{f}_{2}=50 \times \log \left\{\left[1+1 / \mathrm{N} \sum_{\mathrm{i}=1}^{\mathrm{N}}\left(\mathrm{R}_{\mathrm{t}}-\mathrm{T}_{\mathrm{t}}\right)^{2}\right]^{-0.5} \times 100\right\}
$$

Where $\mathrm{N}=$ No. of time points, $\mathrm{R} t=$ Mean $\%$ drug release of reference product and $T t=$ Mean $\%$ drug release of test product. Similarity factor $\mathrm{f} 2$ in the range of 50 to 100 shows similarity between two dissolution profiles.

\section{RESULTS AND DISCUSSION}

Optimization of Naproxen Sodium CR Tablet was done by using $2^{3}$ factorial designs. The summary of data obtained of various responses for Naproxen Sodium CR tablets was shown in Table 5.

\section{Effect of Formulation variables on Disintegration time of tablet ${ }^{15}$}

\section{Summary of ANOVA analysis}

The Model F-value of 85.16 implies the model was significant. $P$-values less than 0.0500 indicate model terms were significant. In this case $\mathrm{AB}, \mathrm{AC}$ was significant model terms. The Lack of Fit F-value of 0.72 implies the Lack of Fit was not significant relative to the pure error. Lack of fit was non-significant which was required to fit well with the experimental design.

\section{Model graphs}

From the interaction graph (Figure 1), it was clear that $\mathrm{AB}$ interaction was significant. This indicates that the impact of factor B i.e. Eudragit RSPO polymer on disintegration time of tablet depends upon the level of A i.e. Eudragit RLPO polymer in the formulation. When factor B (i.e. Eudragit RSPO) is at higher level, Disintegration time of tablet increases with increase in the concentration of Eudragit RLPO. Whereas when the Eudragit RSPO polymer concentration is at lower level, Disintegration time of tablets decreases with increase in the concentration of Eudragit RLPO polymer. 


\begin{tabular}{|c|c|c|c|c|c|}
\hline \multicolumn{6}{|c|}{ Table 5: DOE design layout and observed responses for Naproxen Sodium CR Tablet. } \\
\hline Run & $\begin{array}{c}\text { Factor 1 } \\
\text { A: Eudragit RL PO } \\
\text { mg }\end{array}$ & $\begin{array}{c}\text { Factor 2 } \\
\text { B: Eudragit RS Po } \\
\text { mg }\end{array}$ & $\begin{array}{c}\text { Factor 3 } \\
\text { C: Crospovidone } \\
\text { mg }\end{array}$ & $\begin{array}{c}\text { Response 1 } \\
\text { Disintegration time } \\
\text { minutes }\end{array}$ & $\begin{array}{c}\text { Response 2 } \\
\text { F2 factor of Drug release } \\
\text { \% }\end{array}$ \\
\hline 1 & 94.5 & 129 & 182.25 & 82 & 36.6 \\
\hline 2 & 74.5 & 149 & 162.25 & 87 & 53.15 \\
\hline 3 & 74.5 & 149 & 162.25 & 90 & 53.82 \\
\hline 4 & 94.5 & 169 & 142.25 & 98 & 45.38 \\
\hline 5 & 94.5 & 169 & 182.25 & 100 & 62.25 \\
\hline 6 & 54.5 & 169 & 142.25 & 78 & 50.98 \\
\hline 7 & 54.5 & 169 & 182.25 & 77 & 44.44 \\
\hline 8 & 74.5 & 149 & 162.25 & 101 & 54.49 \\
\hline 9 & 54.5 & 129 & 142.25 & 78 & 74.68 \\
\hline 10 & 94.5 & 129 & 142.25 & 96 & 61.03 \\
\hline 11 & 54.5 & 129 & 182.25 & & 54.91 \\
\hline
\end{tabular}

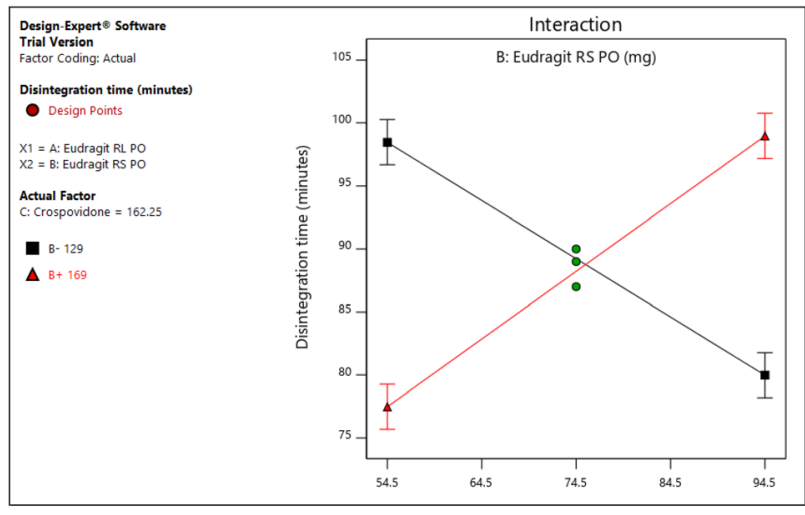

Figure 1: Interaction Plot.

From the contour plot (Figure 2) it showed that $A B$ interaction was significant. As the contour curves had considerable curvature, it implies that the $\mathrm{AB}$ interaction was large and important.

\section{Effect of formulation variables on F2 factor of drug release \\ Summary of ANOVA analysis}

The Model F-value of 486.87 implies the model was significant. $P$-values less than 0.0500 indicate model terms were significant. In this case $A, B, C, A B, A C$, $\mathrm{BC}, \mathrm{ABC}$ were significant model terms. The Lack of Fit F-value of 0.01 implies the Lack of Fit was not significant relative to the pure error. Lack of fit was non-significant which was required to fit well with the experimental design.

\section{Model Graphs}

From Interaction Graph (Figure 3) it was clear that $A B$ interaction was significant. Spread of the points on the right side of the graph (where Eudragit RLPO

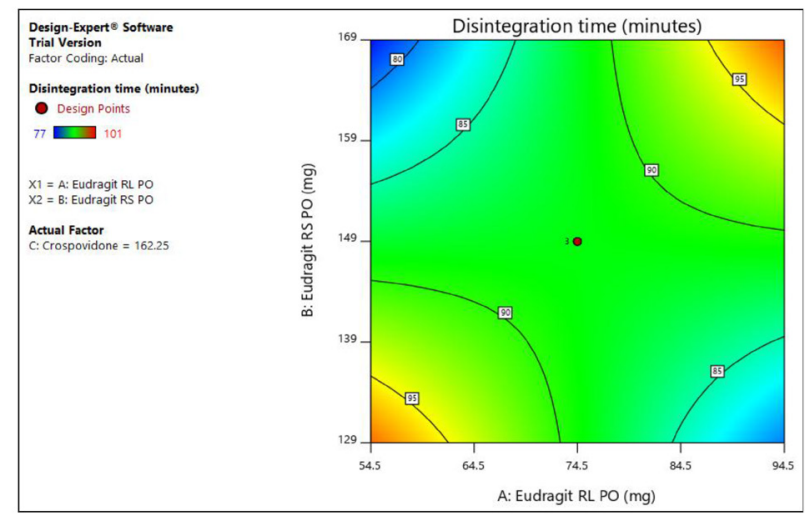

Figure 2: Contour plot.

Concentration is high) was smaller than the spread between the points at the left side of the graph (where Eudragit RLPO conc. was low). In other words, the effect of Eudragit RSPO concentration was less significant at high level of Eudragit RLPO. Therefore, Experiment could run at high Eudragit RLPO polymer concentration and reduce Eudragit RSPO polymer concentration.

From the contour plot (Figure 4) it showed that $\mathrm{AB}$ interaction was significant. As the contour curves had considerable curvature that implies the $\mathrm{AB}$ interaction was large and important.

\section{Evaluation of optimized batch}

From the DOE study F2 batch was found to be optimized batch with $\mathrm{f} 2$ factor of drug release was $53 \%$. It was evaluated as follows.

\section{Evaluation of $C R$ and IR granules}

The CR and IR granules of tablets were evaluated for all following flow properties as shown in Table 6 . Compressibility index of CR and IR granules were 


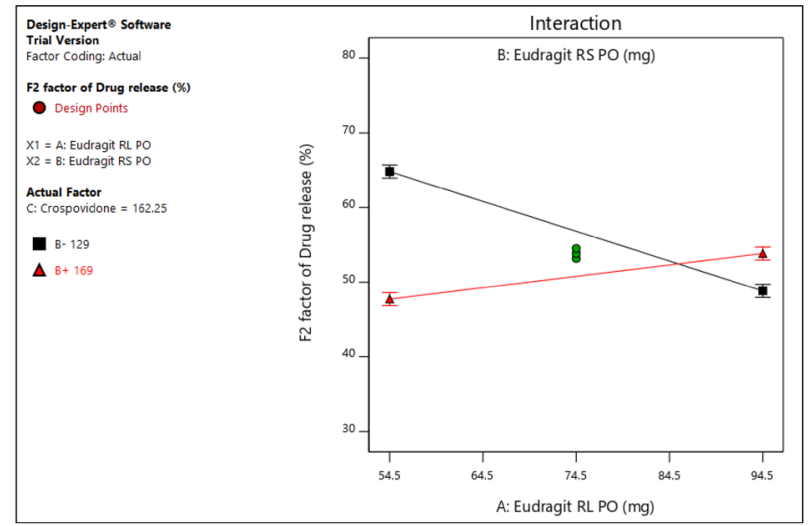

Figure 3: Interaction Plot.

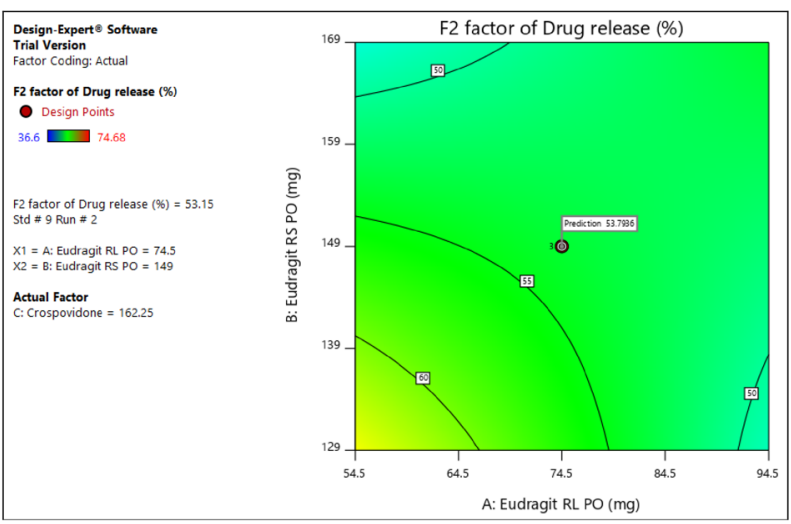

Figure 4: Contour plot.

Table 6: Evaluation of CR and IR granules.

\begin{tabular}{|c|c|c|}
\hline \multirow{2}{*}{ Parameters } & \multicolumn{2}{|c|}{ Results of F2 Batch } \\
\cline { 2 - 3 } & CR granules & IR granules \\
\hline Bulk density (w/v) & 0.47 & 0.59 \\
\hline Tapped density (w/v) & 0.54 & 0.70 \\
\hline Compressibility index (\%) & 12.9 & 15.7 \\
\hline Hausner's ratio & 1.14 & 1.18 \\
\hline
\end{tabular}

found to be $12.9 \%$ and $15.7 \%$ respectively. This value was within the range of 12 to $20 \%$ which indicated that CR and IR granules had good flow. Hauser's ratios of CR and IR granules were found to be 1.14 and 1.18 respectively. This value was within the range of 1.14 to 1.20 which indicates that CR and IR granules had free flow.

\section{Evaluation of Naproxen Sodium CR Tablets}

Tablets of F2 batch were evaluated for appearance, Thickness, Hardness, Friability, Disintegration time, assay and in-vitro dissolution study. Results were summarized in below Table 7 .

\section{Table 7: Evaluation of Naproxen Sodium CR Tablets.}

\begin{tabular}{|c|c|c|}
\hline \multirow{2}{*}{ Sr. No } & Parameters & Results \\
\cline { 3 - 3 } & & Optimized batch (F2) \\
\hline 1 & Appearance & White \\
\hline 2 & Average Wt. (mg) & 1433 \\
\hline 3 & Thickness $(\mathrm{mm})$ & 9.05 \\
\hline 4 & Length $(\mathrm{mm})$ & 22.31 \\
\hline 5 & Hardness $(\mathrm{N})$ & 162 \\
\hline 6 & Friability $(\%)$ & 0.40 \\
\hline 7 & Disintegration Time $(\mathrm{min})$ & 87 \\
\hline
\end{tabular}

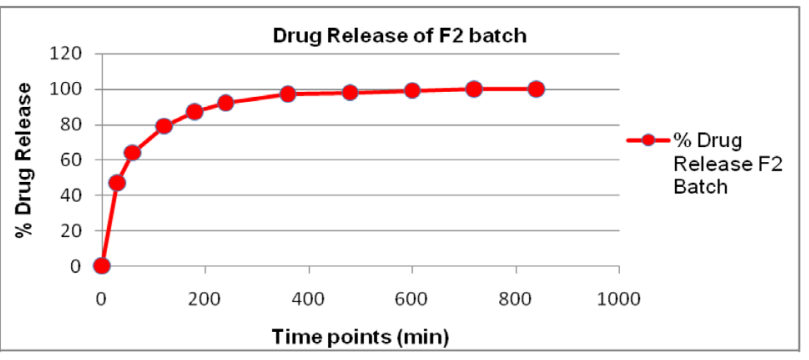

Figure 5: Drug Release profile of F2 batch.

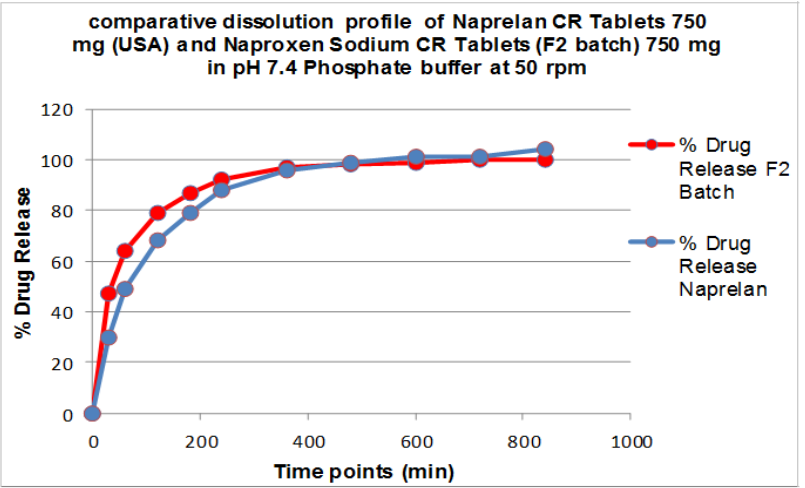

Figure 6: Comparative Dissolution profile.

\section{In vitro dissolution studies}

Dissolution studies for controlled release tablets of Naproxen sodium were carried out in $900 \mathrm{ml}$ of pH.7.4 phosphate buffer in USP Type-2 dissolution apparatus at $50 \mathrm{rpm}$ and $37 \pm 0.50 \mathrm{C}$ for $14 \mathrm{hr}$. Results Demonstrate that when Eudragit RSPO and Eudragit RLPO polymers used in 1:2 ratio, drug released was followed controlled release profile. Drug release profile of F2 batch shown in Figure 5.

\section{Comparative in vitro drug release of optimized batch with marketed product}

Comparative dissolution study (Figure 6) of optimized batch and marketed product were carried out. It was 
found that drug release profile of Naproxen sodium CR release tablet shows comparative drug release profile with marketed product.

\section{CONCLUSION}

The present research work foresees the applicability of QbD in formulating Naproxen sodium CR tablets by using rate retarding polymers that was Eudragit RLPO and Eudragit RSPO. From the result it was clearly evident that as the Eudragit RSPO polymer concentration increases, there was increase the disintegration time of tablet and drug release was decline. The optimized formulation from $2^{3}$ factorial design can be used as a single dose per day in the management of rheumatoid arthritis.

\section{ACKNOWLEDGEMENT}

The authors are grateful to PES Modern College of Pharmacy, Nigdi, Pune, Maharashtra, India and Callidus Research Labs, Chakan Industrial Area, Nighoche, Pune, Maharashtra, India for providing the necessary facilities, assistance and support for carrying out the project.

\section{CONFLICT OF INTEREST}

The authors declare that there is no conflict of interest.

\section{ABBREVIATIONS}

QbD: Quality by Design; DOE: Design of experimentation; ICH: International Conference on Harmonisation; CR: Controlled Release; IR: Immediate Release; MCC: Microcrystalline Cellulose; QTTP: Quality Target Product Profile; CQA: Critical Quality Attribute; BA: Bioavailability; BE: Bioequivalence; USP: United States Pharmacopoeia; UV: Ultraviolet; ANOVA: Analysis of Variance.

\section{REFERENCES}

1. Q9: Quality Risk Management. $\mathrm{ICH}$ Harmonized Tripartite Guidelines. International Conference on Harmonization of Technical Requirements for Registration of Pharmaceuticals for Human Use. 2005.

2. Karkala V, Jinadatharaya H, Gowda D, Sivadasu P. Development and evaluation of Nevirapine Extended Release tablets using $\mathrm{QbD}$ approach. Indian Journal of Pharmaceutical Education and Research. 2018;52(4s):S2208.

3. Annette S, Poul B, Inventor; Nycomed Danmark A/S, assignee. Modified Release Multiple-units Composition of Non-steroidal Anti-inflammatory Drug substances (NSAID). United States Patent US 6,599,529 B1. 2003.

4. Mehta R, Chawla A, Sharma P, Pawar P. Formulation and in vitro evaluation of Eudragit S-100 coated naproxen matrix tablets for colon targeted drug delivery system. Journal of Advanced Pharmaceutical Technology and Research. 2013;4(1):31-41.

5. Sweetman SC. Martindale: The Complete Drug Reference. $36^{\text {th }}$ ed. London, Chicago: Pharmaceutical Press. 2009;92-3.

6. Leon GR, Egidio M, Inventors; Alfa Wassermann SpA, Assignee. Galanic Formulations with programmed Release Containing Naproxen. United States Patent 4,888,178. 1989.

7. Q8(R2): Pharmaceutical Development. ICH Harmonised Tripartite Guidline. International Conference on Harmonization of Technical Requirements for Registration of Pharmaceuticals for Human Use. 2009;1-24.

8. Quality by Design for ANDAs: An Example for Modified Release Dosage Forms: Example QbD MR Tablet, Module 3 Quality, 3.2.P.2 Pharmaceutical Development. 2011;1-161.

9. Singhvi G, Parmar N, Patel N, Saha R. Novel multi granules-controlled release tablets of milnacipran: Design with simplex lattice, in vitro characterization and pharmacokinetics predictions. Journal of Young Pharmacists. 2014;6(3):2431.

10. Apu A, Pathan A, Kibria G, Jalil R. In vitro Release Kinetic Study of Theophylline from Eudragit RS PO and Eudragit RL PO Matrix Tablets. Dhaka Univ J Pharm Sci. 2009;8(1):1-6. Martin A. Micromeritics: Physical pharmacy. Baltimores, MD: Lippincott Williams and Wilkins. 2001;423-54.

11. Islam M, Ahmed I, Quadir M, RahmanH. Once Daily Sustained-Release Matrix Tablet of Naproxen: Formulation and in vitro Evaluation. Dhaka Univ J Pharm Sci. 2010;9(1):47-52.

12. Opeyemi $\mathrm{O}$, Adegbenro $\mathrm{O}$. Development and characterization of direct compressed matrix mini tablets of naproxen sodium. Universal Journal of Pharmaceutical Science. 2018;3(5):68-73.

13. Diaz D, Stephen TC, Connie SL. Dissolution Similarity Requirements: How Similar or Dissimilar Are the Global Regulatory Expectation?. The AAPS Journal. 2016;18(1):15-22.

14. Olawoye B. A Comprehensive Handout on Central Composite Design (CCD). 2016.

15. Available on: https://www.researchgate.net/publication/308608329.

\section{SUMMARY}

- In the present study Naproxen sodium Controlled release tablets were developed and evaluated using QbD approach.

- Eudragit RLPO and Eudragit RSPO were used as rate retarding polymers. Crospovidone was used as disintegrating agent and Magnesium stearate was used as lubricant.

- From the obtained results it was inferred that concentration of Eudragit RSPO and Eudragit RLPO had shown potential effect on disintegration time and drug release profile of tablet. In-vitro drug release studies suggested that formulated tablets had shown a controlled release up to $14 \mathrm{~h}$ when compared with marketed formulation. 


\section{PICTORIAL ABSTRACT}

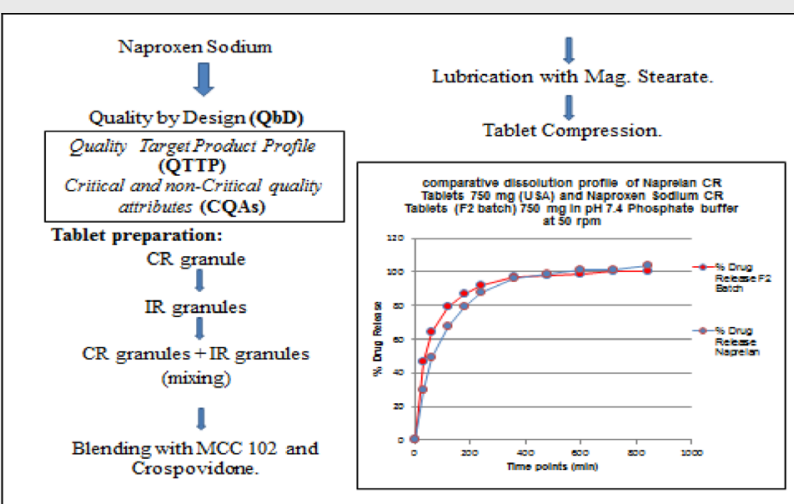

Cite this article: Phatak A, Joshi D, Bhadgale M, Chaudhari P. Development and Optimization of Naproxen Sodium Controlled Release Tablets: ObD Approach. Indian J of Pharmaceutical Education and Research. 2020;54(2s):s108-s116. 